
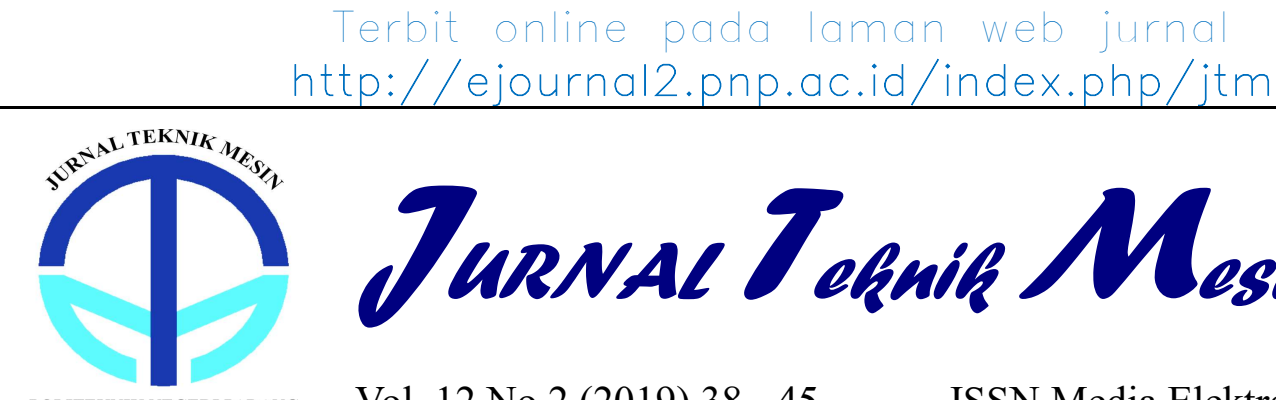

JuRnal Tequili Mesin

POLITEKNIK NEGERI PADANG

Vol. 12 No.2 (2019) $38-45$

ISSN Media Elektronik: 2655-5670

\title{
Analisa Kinematika Monobike Mechanical Toys Menggunakan GNU Octave dan Solidworks
}

\author{
Eva Hertnacahyani Herraprastanti ${ }^{1}$, Suluh Jatmiko ${ }^{2}$ \\ ${ }^{1}$ Program Studi Teknik Mesin, Sekolah Tinggi Teknologi Ronggolawe Cepu \\ ${ }^{2}$ Program Studi Teknik Sipil, Sekolah Tinggi Teknologi Ronggolawe Cepu \\ 1'ev.hertna@gmail.com²si_suluh@gmail.com
}

\begin{abstract}
Industry era 4.0 allows using of cyber technology, both physical and non-physical, in all aspects of life, including the toy industry. Three dimensional printers as a key technology industry 4.0 plays an important role. Before it is printed using a 3D printer, first the product is simulated to find out if toy can move according to the kinematics that we design. This analysis includes the displacement, velocity, linear and angular acceleration of the Monobike component. In this research, the analysis of component movements is limited to Link 3. Monobike mechanical toys mimic human activities of pedaling a bicycle. The methodology in this research is as follows: 1) Determine the dimensions of the monobike component, 2) Determine the monobike drive components, 3) Make a monobike kinematic diagram, 4) Perform kinematic analysis using the position vector of the monobike component, 5) Perform displacement, velocity calculations, and theoretical acceleration with GNU Octave, 6) Perform kinematic analysis with Solidworks, 7) Comparison of theoretical calculation results and Solidworks simulation results. Based on the results of theoretical research and Solidworks simulations, values of displacement, velocity and acceleration are close. The average error for linear displacement is $0.261 \%$, linear velocity $0.852 \%$, linear acceleration $0.7664 \%$, angular velocity $0.372 \%$, and angular acceleration $0.492 \%$. Kinematic analysis in monobike mechanical toys theoretically and simulation with Solidworks software, the results are more or less the same, so it can be said that this research is accurate. Solidworks is recommended as software that can be used to simulate movements in kinematic analysis.
\end{abstract}

Keywords: GNU Octave, Monobike, Mechanical Toys, Kinematics

\begin{abstract}
Abstrak
Era industry 4.0 memungkinkan penggunaan teknologi cyber, tidak terkecuali pada industri mainan. Printer 3 Dimensi sebagai teknologi kunci industry 4.0 memegang peranan penting. Sebelum dicetak menggunakan printer 3D, menjadi sebuah produk real, terlebih dahulu produk disimulasi unt mengetahui apakah produk mainan tersebut bisa bergerak sesuai gerakan kinematika yang kita rancang. Tujuan penelitian adalah untuk menganalisis gerakan komponen pada Monobike secara teoritis dengan GNU Octave dan dengan simulasi perangkat lunak Solidwork. Analisis ini mencakup displacement, kecepatan, dan percepatan linier dan angular komponen Monobike. Dalam penelitian ini analisis gerakan komponen dibatasi hanya pada Link 3. Dalam penelitian ini ditentukan mainan yang dapat meniru gerak suatu benda setepat mungkin, yaitu mainan monobike. Mainan mekanik monobike meniru aktivitas manusia mengayuh sepeda roda satu. Metode penelitian ini adalah sebagai berikut :1) Menentukan dimensi komponen monobike, 2) Menentukan komponen penggerak monobike, 3) Membuat diagram kinematis monobike, 4) Melakukan analisa kinematis dengan menggunkan vector posisi dari komponen monobike, 5) Melakukan perhitungan displacement, kecepatan, dan percepatan secara teoritis dengan GNU Octave, 6) Melakukan analisis kinematis dengan Solidworks, 7) Melakukan perbandingan hasil perhitungan secara teori dan hasil simulasi Solidworks. Berdasarkan hasil penelitian teoritis dan simulasi Solidworks, nilai perpindahan, kecepatan dan akselerasi sangat dekat. Kesalahan rata-rata untuk perpindahan linier adalah 0,261\%, kecepatan linier 0,852\%, percepatan linier 0,7664\%, kecepatan sudut 0,372\%, dan percepatan sudut $0,492 \%$. Analisis kinematik pada mainan mekanik monobike secara teoritis dan simulasi Solidworks, hasilnya kurang lebih sama, sehingga dapat dikatakan bahwa penelitian ini akurat. Solidworks
\end{abstract}


direkomendasikan sebagai perangkat lunak yang dapat digunakan untuk mensimulasikan gerakan dalam analisis kinematik.

Kata kunci: GNU Octave, Monobike, Mechanical Toys, Kinematika.

\section{Pendahuluan}

Kemajuan teknologi sudah dirasakan semua lapisan masyarakat. Generasi muda sekarang, bahkan usia anak-anak sudah dikenalkan dengan gadget (gawai)[8]. Gawai seakan tak bisa dilepaskan dari keseharian. Tak terkecuali bagi anak dan orangtua. Bagi orangtua, gawai kerap dijadikan pengalih perhatian anak ketika mereka punya kesibukan. Misalnya, ketika sang anak menangis, atau ketika orangtua melakukan pekerjaan rumah dan berharap si anak diam tidak rewel. Maka, gawai dijadikan senjata untuk membuat anak tenang. Tetapi, sejumlah fenomena soal kecanduang gadget yang terjadi belakangan ini, harus menjadi perhatian.

Pusat Pengembangan Pendidikan Anak Usia Dini (PAUD) dan Pendidikan Keluarga untuk regional Asia Tenggara (ASEAN) atau Southeast Asian Ministers of Education Regional Centre for Early Childhood Care and Education and Parenting (SEAMEO CECCEP) berupaya mencari solusi untuk mengurangi kecanduan gawai pada anak balita (Perdana \& Assifa, 2019). Salah satu poin yang akan dicari di konferensi ini adalah bagaimana mengatasi kecanduan gadget anak balita dengan salah satu penekanan dalam hasil penelitian tersebut adalah mendisiplinkan pola asuh orangtua kepada anak, juga lebih memperhatikan mainan yang dipakai anak. Orang tua hendaknya bijak dalam memilih mainan, yaitu minimal bisa memberi beragam manfaat dan merangsang kreativitas dan daya pikir anak.

Industri mainan dalam negeri diprediksi tumbuh sebesar 10 persen di tahun 2019, menurut Ketua Asosiasi Mainan Anak (AMI) Sutjiadi Lukas (Gloria, 2019[2]. Hal ini menjadi pasar yang sangat menjanjikan bagi industri mainan dalam negeri. Ada beberapa langkah penting untuk menentukan mainan sesuai dengan kelompok usia anak, seperti mempertimbangkan aspek fisik, kognitif, sosial, dan emosional anak [2]. Pada usia 6-9 bulan misalnya, ketika anak sudah mulai belajar untuk bergerak, mainan yang diberikan haruslah yang bisa mengasah kemampuan motorik anak.

Mainan memang bisa memberikan proses yang baik dalam proses pembelajaran dan tumbuh kembang anak. Director of Early Childhood Development Research Fisher Price, Deborah Weber memandang pentingnya metode STEM [2], yaitu Sains, Teknologi, Teknik (engineering), dan Matematika dalam perkembangan mainan anak usia dini. Metode ini akan menstimulasi anak untuk memecahkan masalah, fokus pada solusi, membangun cara berpikir logis dan sistematis, serta mempertajam kemampuan berpikir kritis.

Mechanical Toys adalah mainan yang memanfaatkan sebagian besar proses mekanis yang dapat ditemukan pada bagian mesin seperti cam, roda gigi, ratchets dan engkol [9]. Mechanical Toys diyakini mampu mempertajam kemampuan berpikir kritis, melatih daya pikir dan motorik anak.

Ada beberapa mechanical toys yang sudah dijual dipasaran, contohnya adalah mainan Code-A-Pillar dari Fisher Price [2], yang memiliki bentuk seperti ulat, dan bisa dimainkan pada anak berumur tiga tahun ke atas. Pada mainan ini, anak ditantang untuk menyusun bagian tubuh ulat dengan bagian-bagian yang memiliki fungsi arah masing-masing. Anak akan terstimulasi untuk menganalisis cara si ulat bisa mencapai tujuan tertentu dengan susunan bagian yang tepat. Mainan ini adalah contoh mainan mekanik pemanfaatan teknologi untuk belajar anak.

Pada paper ini, mechanical toys yang akan dibahas adalah Monobike [4], yaitu mainan berbentuk sepeda roda satu. Mengapa dipilih sepeda sebagai mainan anak? Karena bersepeda merupakan aktivitas yang paling digemari anak. Dengan bersepeda anak berlatih untuk berani, dan mengembangkan keterampilan motorik kasar [5]. Bersepeda membutuhkan tingkat keseimbangan dan koordinasi tertentu sehingga untuk anak-anak yang belum lancar berjalan dan kurang memiliki konsentrasi dan keseimbangan yang cukup maka akan sulit dalam menggunakan sepeda. Proses mekanis yang ada pada Monobike yaitu menirukan gerakan slider crank pada poros engkol (kruk as) dari suatu bagian mesin.

Sedangkan analisa yang akan dibahas pada Monobike yaitu dari sisi penggeraknya (kinematikanya). Kinematika adalah ilmu yang mempelajari tentang gerak [3]. Gerakan suatu benda disebabkan karena suatu gaya dorong. Pada sepeda gaya dorong berasal dari kayuhan kaki yang dilakukan. Gaya dorong yang dilakukan tersebut menyebabkan kendaraan yang semula diam, akan bergerak dengan percepatan dan kecepatan tertentu. Pada Monobike, gaya dorong berasal dari kayuhan kaki yang memutar pedal dan bergerak naik turun. Gerakan naik turun pedal tersebut akan memutar roda kedua dan menyebabkan body boneka yang memegang kipas juga bergerak naik turun. Mekanisme gerakan Monobike ditampilkan pada Gambar 1. 


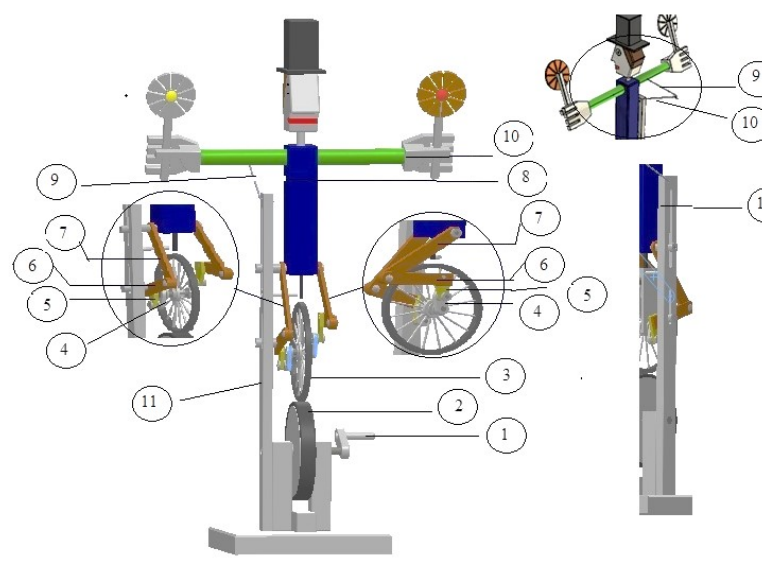

Keterangan :

1. tuas pemutar

7. $\operatorname{link} 4$

2. piringan pemutar

8. bodi

3. roda

9. $\operatorname{link} 6$

4. link 1

10. link 7

5. $\operatorname{link} 2$

6. $\operatorname{link} 3$

\section{Gambar 1. Komponen Monobike [4]}

Membuat mechanical toys merupakan hal yang menarik, yang mencakup berbagai keterampilan, seni, teknik dan sains. Dalam pembuatan mechanical toys tetap berprinsip pada mekanika sederhana yang terdapat satu mekanisme atau lebih.

Monobike dirancang menggunakan alat bantu software Solidworks 2016. Dengan menggunakan Solidworks 2016 produk yang sudah digambar disimulasikan terlebih dahulu untuk mengetahui apakah produk mainian tersebut bisa bergerak dengan sesuai gerakan kinematika yang dirancang. Setelah melakukan analisa kinematika, selanjutnya melakukan sintesa yaitu menganalisis gerak setiap bagian mechanical toys yang direncanakan berdasar dimensi yang telah ditetapkan [7]. Selanjutnya Monobike dianalisa yang meliputi analisis posisi dan kecepatan menggunakan GNU Octave.

GNU Octave merupakan perangkat lunak gratis (freeware) untuk komputasi numerik dan visualisasi data. Octave dirancang sebagai tiruan dari Matlab yang memiliki kelebihan selain gratis, Octave tersedia untuk berbagai sistem operasi seperti Windows 98/2000/XP, Mac OS/X, Debian, Suse, Fedora, dan RedHat Linux [1]

Adapun tujuan penelitian adalah untuk mengaplikasikan GNU Octave dalam menganalisis gerakan komponen pada Monobike yang meliputi analisa displacement, kecepatan, dan percepatan secara linier maupun angular. Dalam penelitian ini analisis gerakan komponen dibatasi hanya pada Link 3 pada Gambar 1 .
Sedangkan gerakan kinematika yang dibahas adalah mekanisme slider crank pada monobike [5]. Dipilih mekanisme slider crank karena mekanisme tersebut terdapat pada banyak gerakan mekanik suatu mesin, misalnya pada gerakan poros engkol (kruk as).

\section{Metode Penelitian}

Dalam penelitian ini ditentukan mainan yang dapat meniru gerakan suatu benda setepat mungkin, yaitu monobike. Monobike meniru aktivitas manusia mengayuh sepeda. Metodologi dalam penelitian ini adalah sebagai berikut: a) Tentukan dimensi komponen monobike, b) Tentukan komponen penggerak monobike c) Membuat diagram kinematika monobike d) Melakukan analisis kinematika menggunakan vektor posisi komponen monobike, e) Melakukan perhitungan perpindahan, kecepatan dan akselerasi dengan GNU Octave, f) Lakukan analisis kinematik dengan Solidworks g) Buat perbandingan hasil GNU Octave dan hasil simulasi Solidworks.

Adapun tempat melaksanakan penelitian di Laboratorium Komputer Teknik Mesin STT Ronggolawe Cepu dan waktu pelaksanaan penelitian selama 3 bulan sejak bulan Juni sampai dengan Agustus 2019.

\section{Hasil dan Pembahasan}

Mekanisme slider crank yang digunakan pada monobike, seperti diperlihatkan pada Diagram Kinematika pada Gambar 2 :

Adapun panjang $\mathrm{L}_{2}=7 \mathrm{~mm}, \mathrm{~L}_{3}=11.38 \mathrm{~mm}, \mathrm{~L}_{4}=$ $25.04 \mathrm{~mm}, \mathrm{~L}_{5}=40 \mathrm{~mm}, \mathrm{~L}_{6}=42 \mathrm{~mm}, \mathrm{~L}_{7}=40 \mathrm{~mm}, \mathrm{~L}_{8}$ $=53 \mathrm{~mm}, \mathrm{~L}_{9}=38 \mathrm{~mm}, \Omega 2=50 \mathrm{rpm}$

Untuk menentukan sudut $\theta_{3}$ yang diilustrasikan dalam diagram kinematik pada Gambar 2 (b) menggunakan aturan segitiga siku-siku.

$$
A B=L_{2} \cos \theta_{2}
$$

Sedangkan,

$$
\cos \phi=\frac{A B}{L_{3}}
$$

Sehingga,

$$
\begin{gathered}
\phi=\cos ^{-1}\left(\frac{L_{2} \cos \theta_{2}}{L_{3}}\right) \\
\theta_{3}=180-\phi \\
\beta=\theta_{2}+\phi
\end{gathered}
$$

Menentukan Displacement Titik C

Displacement Titik C ditentukan dengan menggunakan rumus Cosinus

$$
L_{1}=\sqrt{L_{2}^{2}+L_{3}^{2}-2 L_{2} L_{3} \cos \beta}
$$




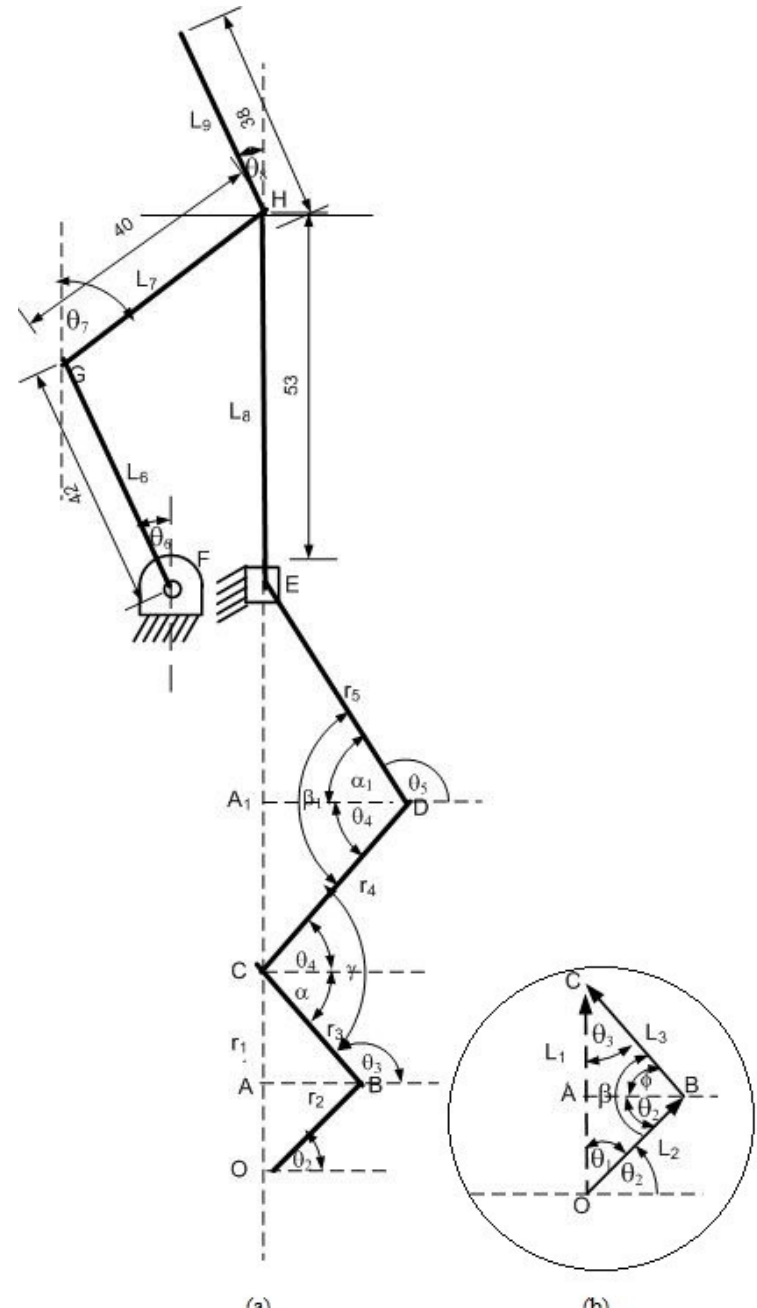

(a) (b)

Gambar 2. Diagram Kinematika Monobike

\subsection{Analisa Kecepatan}

Analisa kececpatam ditentukan dengan menentukan persamaan posisi titik $\mathrm{C}$ terhadap waktu. Persamaan posisi titik $\mathrm{C}$ adalah

$$
\overline{L_{1}}=\overline{L_{2}}+\overline{L_{3}}
$$

Dengan metode bilangan kompleks persamaan posisi titik $\mathrm{C}$ adalah sebagai berikut :

$$
\begin{gathered}
L_{1} e^{i \theta_{1}}=L_{2} e^{i \theta_{2}}+L_{3} e^{i \theta_{3}} \\
\frac{d}{d t}\left(L_{1} e^{i \theta_{1}}\right)=\frac{d}{d t}\left(L_{2} e^{i \theta_{2}}+L_{3} e^{i \theta_{3}}\right) \\
L_{1} e^{i \theta_{1}}=i \theta_{2} L_{2} e^{i \theta_{2}}+i \theta_{3} L_{3} e^{i \theta_{3}}
\end{gathered}
$$

Dimana $\dot{\theta}=\omega$ sehingga

$$
\begin{aligned}
& \dot{\mathrm{L}}_{1} \mathrm{e}^{\mathrm{i} \theta_{1}}=\mathrm{i} \dot{\omega}_{2} \mathrm{~L}_{2} \mathrm{e}^{\mathrm{i} \theta_{2}}+\mathrm{i} \theta_{3} \mathrm{~L}_{3} \mathrm{e}^{\mathrm{i} \theta_{3}} \\
& \dot{L}_{1}\left(\cos \theta_{1}+i \sin \theta_{2}\right)=i \dot{\omega}_{2} L_{2}\left(\cos \theta_{1}+i \sin \theta_{2}\right)+i \theta_{3} L_{3}\left(\cos \theta_{3}+i \sin \theta_{3}\right)
\end{aligned}
$$

$\dot{L_{1}}=\omega_{2} L_{2} \cos \theta_{2} i-\omega_{2} L_{2} \sin \theta_{2}+\omega_{3} L_{3} \cos \theta_{2} i-\omega_{3} L_{3} c \sin \theta_{3}$

Persamaan (13) diuraikan menjadi komponen riil dan imajiner

$$
\begin{array}{r}
0=-\omega_{2} L_{2} \sin \theta_{2}-\omega_{3} L_{3} \sin \theta_{3} \\
\check{L_{1}}=\omega_{2} L_{2} \cos \theta_{2}+\omega_{3} L_{3} \cos \theta_{3}
\end{array}
$$

Dari persamaan (15) diperoleh :

$$
\omega_{3}=\frac{-\omega_{2} L_{2} \sin \theta_{2}}{L_{3} \sin \theta_{3}}
$$

Dari persamaan (16) diperoleh Kecepatan titik C yaitu:

$$
V_{C}=\omega_{2} L_{2} \cos \theta_{2}+\omega_{3} L_{3} \cos \theta_{3}
$$

\subsection{Analisa Percepatan}

Percepatan titik $\mathrm{C}$ ditentukan dengan menurunkan persamaan (11) terhadap waktu

$$
\begin{gathered}
\frac{d}{d t}\left(L_{1} e^{i \theta_{1}}\right)=\frac{d}{d t}\left(L_{2} e^{i \theta_{2}}+L_{3} e^{i \theta_{3}}\right) \\
\frac{d}{d t}\left(\dot{L}_{1} e^{i \theta_{1}}\right)=\frac{d}{d t}\left(i \omega_{2} L_{2} e^{i \theta_{2}}\right)+\frac{d}{d t}\left(i \omega_{3} L_{3} e^{i \theta_{3}}\right)
\end{gathered}
$$

Dimana $\theta_{1}=\frac{n}{2}$

$$
\ddot{L_{1}} e^{i \frac{\pi}{2}}=i \dot{\omega}_{2} L_{2} e^{i \theta_{2}}-\omega_{2}^{2} L_{2} e^{i \theta_{2}}+i \dot{\omega}_{3} L_{3} e^{i \theta_{3}}-\omega_{3}^{2} L_{3} e^{i \theta_{3}}
$$

Dimana $\omega=\alpha$, sehingga :

$$
\begin{aligned}
& \ddot{L}_{1}\left(\cos \frac{\pi}{2}+i \sin \frac{\pi}{2}\right)=i \alpha_{2} L_{2}\left(\cos \theta_{2}+i \sin \theta_{2}\right)-\omega_{2}^{2} L_{2}\left(\cos \theta_{2}+\right. \\
& \left.i \sin \theta_{2}\right)+i \alpha_{3} L_{3}\left(\cos \theta_{3}+i \sin \theta_{3}\right)-\omega_{3}^{2} L_{3}\left(\cos \theta_{3}+i \sin \theta_{3}\right)
\end{aligned}
$$

$\ddot{L_{1}}=\alpha_{2} L_{2} \cos \theta_{2} i-\alpha_{2} L_{2} \sin \theta_{2}-\omega_{2}^{2} L_{2} \cos \theta_{2}-\omega_{2}^{2} L_{2} \sin \theta_{2} i+$ 
Persamaan (22) diuraiakan menjadi komponen real dan imaginer :

$$
\begin{aligned}
& -\alpha_{2} L_{2} \sin \theta_{2}-\omega_{2}^{2} L_{2} \cos \theta_{2}-\alpha_{3} L_{3} \sin \theta_{3}-\omega_{3}^{2} L_{3} \cos \theta_{3}=0 \\
& \alpha_{2} L_{2} \cos \theta_{2}-\omega_{2}^{2} L_{2} \sin \theta_{2}-\alpha_{3} L_{3} \cos \theta_{3}-\omega_{3}^{2} L_{3} \sin \theta_{3}=\ddot{L}_{1}
\end{aligned}
$$

\subsection{Percepatan Linier Titik C}

Untuk menentukan percepatan linier titik C, persamaan (23) dikalikan $\cos \theta_{3}$ dan persamaan (24) dikalikan $\sin \theta_{3}$ kemudian ditambahkan, diperoleh

$$
\begin{aligned}
& -\alpha_{2} L_{2} \sin \theta_{2} \cos \theta_{2}-\omega_{2}^{2} L_{2} \cos \theta_{2} \sin \theta_{2}-\alpha_{3} L_{3} \sin \theta_{3} \cos \theta_{3}- \\
& \omega_{3}^{2} L_{3} \cos \theta_{3} \cos \theta_{3}=0 \\
& \alpha_{2} L_{2} \cos \theta_{2} \sin \theta_{3}-\omega_{2}^{2} L_{2} \sin \theta_{2} \sin \theta_{3}+\alpha_{3} L_{3} \cos \theta_{3} \sin \theta_{3}- \\
& \omega_{3}^{2} L_{3} \sin \theta_{3} \sin \theta_{3}=\check{L}_{1} \sin \theta_{3}
\end{aligned}
$$

$-\alpha_{2} L_{2}\left(\sin \theta_{2} \cos \theta_{3}-\cos \theta_{2} \sin \theta_{3}\right)-\omega_{2}^{2} L_{2}\left(\cos \theta_{2} \cos \theta_{3}+\sin \theta_{2} \sin \theta_{3}\right)-$ $\omega_{3}^{2} L_{3}\left(\cos ^{2} \theta_{3}+\sin ^{2} \theta_{3}\right)-\alpha_{2} L_{2} \sin \left(\theta_{3}-\theta_{3}\right)+\omega_{3}^{2} L_{3}=L_{1} \sin \theta_{3}$

$A_{C}=\ddot{L_{1}}=\frac{-\alpha_{2} L_{2} \sin \left(\theta_{2}-\theta_{3}\right)-\omega_{2}^{2} L_{2} \cos \left(\theta_{2}-\theta_{3}\right)-\omega_{3}^{2} L_{2}}{\sin \theta_{3}}$
3.4 Percepatan sudut link 3

Untuk menentukan percepatan sudut link3, persamaan (23) dikalikan sin $\theta 3$ dan persamaan (24) dikalikan $\cos \theta 3$, kemudian dikurangkan, diperoleh :

$$
\begin{aligned}
& -\alpha_{2} L_{2} \sin \theta_{2} \sin \theta_{3}-\omega_{2}^{2} L_{2} \cos \theta_{2} \sin \theta_{3}-\alpha_{3} L_{3} \sin \theta_{3} \sin \theta_{3}- \\
& \omega_{2}^{2} L_{2} \cos \theta_{2} \sin \theta_{3}=0 \\
& \alpha_{2} L_{2} \cos \theta_{2} \cos \theta_{3}-\omega_{2}^{2} L_{2} \sin \theta_{2} \cos \theta_{3}+\alpha_{3} L_{3} \cos \theta_{3} \cos \theta_{3}- \\
& \omega_{2}^{2} L_{3} \sin \theta_{3} \cos \theta_{3}=\ddot{L}_{1} \cos \theta_{3} \\
& \frac{-\alpha_{2} L_{2}\left(\sin \theta_{2} \sin \theta_{3}+\cos \theta_{2} \cos \theta_{3}\right)+\omega_{2 . .2}^{2} L_{2}\left(\sin \theta_{3} \cos \theta_{3}-\right.}{\left.\cos \theta_{3} \sin \theta_{3}\right)-\alpha_{3} L_{3}\left(\sin \theta_{3}+\cos \theta_{3}\right)=-L_{2} \cos \theta_{3}} \\
& \alpha_{3} L_{3}=\ddot{L}_{1} \cos \theta_{3}-\alpha_{2} L_{2} \cos \left(\theta_{2}-\theta_{3}\right)+\omega_{2}^{2} L_{2} \sin \left(\theta_{2}-\theta_{3}\right) \\
& \alpha_{3}=\frac{-\ddot{L}_{1} \sin \left(\theta_{3}-\theta_{1}\right)-\omega_{1} L_{1} \cos \left(\theta_{1}+\theta_{3}\right)+\omega_{2}^{2} L_{2} \sin \left(\theta_{2}+\theta_{3}\right)+\alpha_{2} L_{2}}{L_{3}\left(\sin ^{2} \theta_{3}-\cos ^{2} \theta_{3}\right)}
\end{aligned}
$$

\begin{tabular}{|c|c|c|c|c|c|c|c|c|}
\hline $\begin{array}{c}\text { Angle } \theta_{2} \\
(\mathrm{deg})\end{array}$ & $\begin{array}{l}\text { Angle } \phi \\
(\mathrm{deg})\end{array}$ & $\begin{array}{c}\text { Angle } \beta \\
\text { (deg) }\end{array}$ & $\begin{array}{c}\text { Angle } \theta_{3} \\
(\mathrm{deg}) \\
\end{array}$ & $\begin{array}{c}\mathrm{L}_{1} \\
(\mathrm{~mm}) \\
\end{array}$ & $\begin{array}{c}\text { Linier } \\
\text { Displacement } \\
\omega_{3} \\
(\mathrm{~mm} / \mathrm{sec}) \\
\end{array}$ & $\begin{array}{c}\text { Linier } \\
\text { Acceleration } \\
\mathrm{mm} / \mathrm{sec} \\
\end{array}$ & $\begin{array}{l}\text { Angular } \\
\text { Velocity } \\
\mathrm{rad} / \mathrm{sec} 2\end{array}$ & $\begin{array}{c}\text { Angular } \\
\text { Acceleration } \\
\alpha_{3} \\
(\mathrm{deg}) \\
\end{array}$ \\
\hline 0 & 51.901 & 51.901 & 128.099 & 8.955 & 8.955 & 36.633 & 0.000 & $-1,223.135$ \\
\hline 30 & 57.657 & 87.657 & 122.343 & 13.114 & 13.114 & 43.288 & -108.846 & -856.185 \\
\hline 60 & 71.893 & 131.893 & 108.107 & 16.878 & 16.878 & 28.659 & -167.589 & -346.695 \\
\hline 90 & 89.756 & 179.756 & 90.244 & 18.380 & 18.380 & 0.156 & -183.950 & 2.331 \\
\hline 120 & 107.619 & 227.619 & 72.381 & 16.909 & 16.909 & -28.364 & -167.165 & 350.397 \\
\hline 150 & 121.858 & 271.858 & 58.142 & 13.168 & 13.168 & -43.079 & -108.328 & 854.551 \\
\hline 180 & 127.619 & 307.619 & 52.381 & 9.017 & 9.017 & -36.640 & -0.054 & $1,215.408$ \\
\hline 210 & 121.868 & 331.868 & 58.132 & 6.168 & 6.168 & -20.378 & 108.253 & 855.045 \\
\hline 240 & 107.634 & 347.634 & 72.366 & 4.785 & 4.785 & -8.268 & 167.134 & 350.763 \\
\hline 270 & 89.772 & 359.772 & 90.228 & 4.380 & 4.380 & -0.154 & 183.950 & 2.609 \\
\hline 300 & 71.908 & 371.908 & 108.092 & 4.754 & 4.754 & 7.971 & 167.620 & -346.328 \\
\hline 330 & 57.666 & 387.666 & 122.334 & 6.113 & 6.113 & 20.150 & 108.921 & -855.683 \\
\hline 360 & 51.901 & 411.901 & 128.099 & 8.952 & 8.952 & 36.620 & 0.108 & $-1,223.134$ \\
\hline
\end{tabular}

Kemudian gerakan kaki monobike disimulasikan dengan solidworks, dan digerakkan pada 50 RPM, sehingga kecepatan linier dan akselerasi diketahui, seperti yang ditunjukkan pada Tabel 1 .

Tabel 1. Hasil dengan GNU Octave 
Sedangkan hasil dari simulasi Solidwork ditunjukkan pada tabel 2 berikut :

Tabel 2. Hasil dengan Solidworks

\begin{tabular}{|c|c|c|c|c|c|c|c|c|}
\hline $\begin{array}{c}\text { Angle } \theta_{2} \\
(\operatorname{deg})\end{array}$ & $\begin{array}{c}\text { Angle } \phi \\
\text { (deg) }\end{array}$ & $\begin{array}{l}\text { Angle } \beta \\
\text { (deg) }\end{array}$ & $\begin{array}{c}\text { Angle } \theta_{3} \\
(\mathrm{deg}) \\
\end{array}$ & $\begin{array}{c}\mathrm{L}_{1} \\
(\mathrm{~mm}) \\
\end{array}$ & $\begin{array}{c}\text { Linier } \\
\text { Displacement } \\
\omega_{3} \\
\mathrm{~mm} / \mathrm{sec}\end{array}$ & $\begin{array}{c}\text { Linier } \\
\text { Acceleration } \\
\mathrm{mm} / \mathrm{sec} \\
\end{array}$ & $\begin{array}{l}\text { Angular } \\
\text { Velocity } \\
\mathrm{rad} / \mathrm{sec} 2\end{array}$ & $\begin{array}{c}\text { Angular } \\
\text { Acceleration } \\
\alpha_{3} \\
(\mathrm{deg}) \\
\end{array}$ \\
\hline 0 & 51.901 & 51.901 & 128.099 & 8.955 & 8.976 & 36.667 & -0.123 & $-1,225.485$ \\
\hline 30 & 57.657 & 87.657 & 122.343 & 13.114 & 13.135 & 43.273 & -109.110 & -857.588 \\
\hline 60 & 71.893 & 131.893 & 108.107 & 16.878 & 16.893 & 28.562 & -167.987 & -348.173 \\
\hline 90 & 89.756 & 179.756 & 90.244 & 18.380 & 18.380 & 0.153 & -184.534 & 2.315 \\
\hline 120 & 107.619 & 227.619 & 72.381 & 16.909 & 16.888 & -28.609 & -167.917 & 349.005 \\
\hline 150 & 121.858 & 271.858 & 58.142 & 13.168 & 13.127 & -43.281 & -108.938 & 858.725 \\
\hline 180 & 127.619 & 307.619 & 52.381 & 9.017 & 8.969 & -36.637 & -0.053 & $1,225.485$ \\
\hline 210 & 121.868 & 331.868 & 58.132 & 6.168 & 6.129 & -20.191 & 109.110 & 857.588 \\
\hline 240 & 107.634 & 347.634 & 72.366 & 4.785 & 4.765 & -8.057 & 167.987 & 348.173 \\
\hline 270 & 89.772 & 359.772 & 90.228 & 4.380 & 4.380 & -0.157 & 184.534 & 2.631 \\
\hline 300 & 71.908 & 371.908 & 108.092 & 4.754 & 4.767 & 8.076 & 167.917 & -349.005 \\
\hline 330 & 57.666 & 387.666 & 122.334 & 6.113 & 6.133 & 20.221 & 108.938 & -858.725 \\
\hline 360 & 51.901 & 411.901 & 128.099 & 8.952 & 8.976 & 36.667 & 0.108 & $-1,225.485$ \\
\hline
\end{tabular}

Sedangkan nilai-nilai Linier Displacement, Kecepatan dan Percepatan Linier dan Angular ditampilkan dalam gambar $3 \mathrm{~s} / \mathrm{d} 7$.

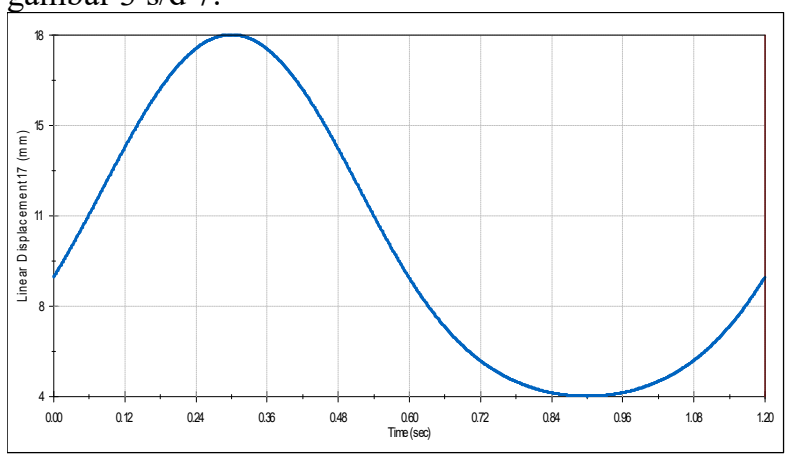

Gambar 3. Linier Displacement Monobike

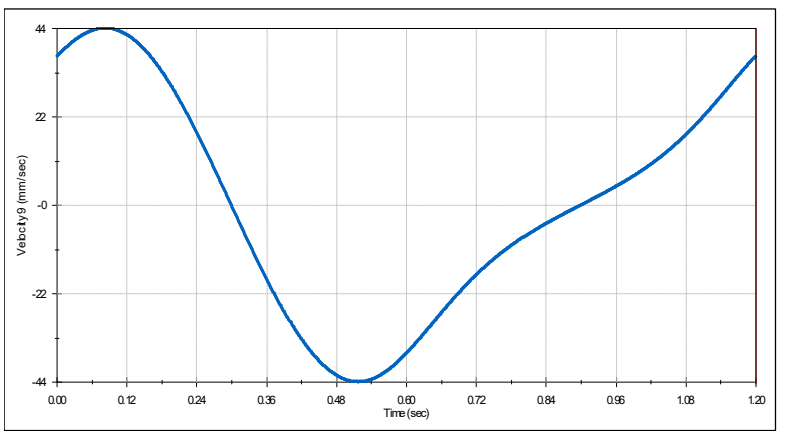

Gambar 4. Kecepatan Linier Monobike

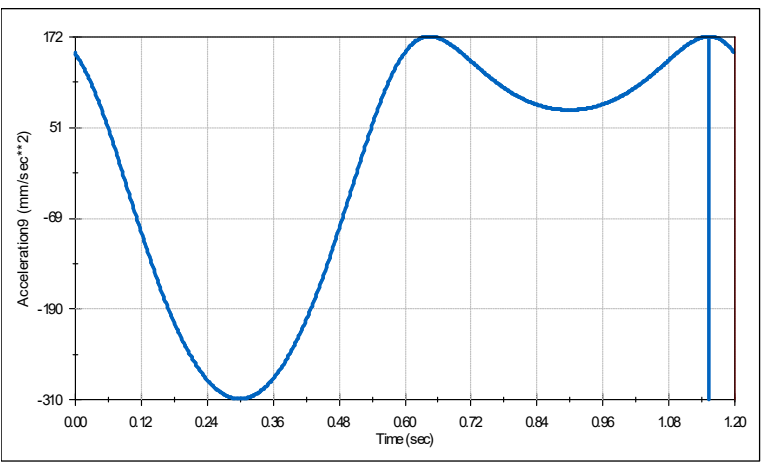

Gambar 5 Percepatan Angular Monobike

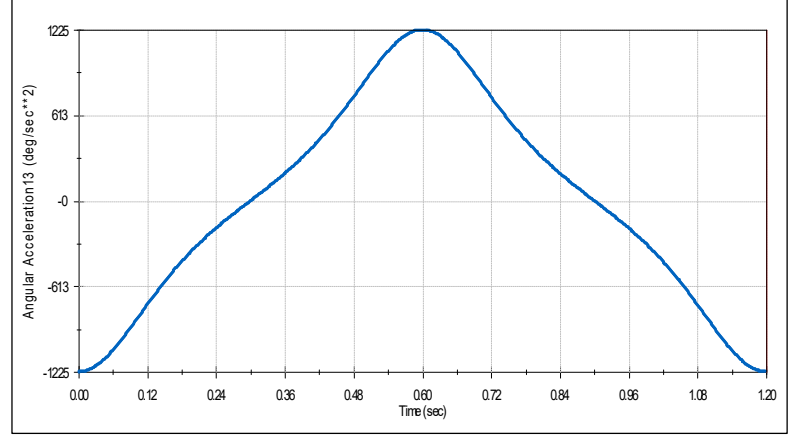

Gambar 6 Kecepatan Angular Monobike

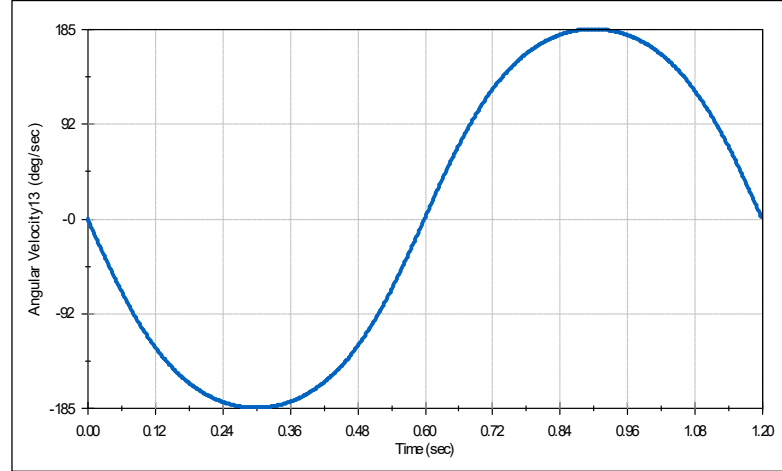

Gambar 7 Kecepatan Angular Monobike

3.5 Perbandingan GNU Octave dan Solidworks

Analisis kinematik slider crank dalam mainan monobike menggunakan GNU Octave dan simulasi dengan perangkat lunak Solidworks, hasilnya kurang lebih sama. Untuk menghitung perbandingan nilai GNU Octave dan simulasi solidworks secara akurat, diperlukan perhitungan kesalahan persentase dengan menggunakan rumus berikut:

$\%$ Kesalahan $=\frac{\text { Nilai Teoritis }- \text { Nilai Eksperimen }}{\text { Nilai Teoritis }} \times 100$ 
Dimana:

- Nilai teoretis adalah data yang dihitung oleh GNU Octave, seperti ditunjukkan pada Tabel 1
- Nilai eksperimental adalah data yang diperoleh melalui simulasi dengan SolidWorks seperti yang ditunjukkan pada Tabel 2.

- Prosentase Nilai Kesalahan antara Nilai Teoritik GNU Octave dengan Simulasi Solidwork pada tabel 3 .

Tabel 3. Prosentase Nilai Kesalahan antara Nilai Teoritik GNU Octave dengan Simulasi Solidworks

\begin{tabular}{crrrrr}
\hline Angle $\theta_{2}$ & Lin Disp & Linier Velocity & Linier Acceleration & Angular Velocity & Angular Acceleration \\
\hline 0 & 0.235706 & 0.091637726 & 0.430597934 & 0 & 0.192130571 \\
30 & 0.163473 & 0.035871654 & 2.322993203 & 0.242763223 & 0.163870837 \\
60 & 0.091146 & 0.339585145 & 0.416345178 & 0.237442904 & 0.426327224 \\
90 & 0.00023 & 1.702859768 & 0.309747579 & 0.317600644 & 0.693160467 \\
120 & 0.128488 & 0.865780677 & 0.244825158 & 0.450136446 & 0.397339081 \\
150 & 0.313898 & 0.468491518 & 1.977068524 & 0.562985383 & 0.488423649 \\
180 & 0.534141 & 0.008003807 & 1.425651758 & 1.14953537 & 0.829060274 \\
210 & 0.626186 & 0.918213705 & 0.389058923 & 0.791920727 & 0.297351265 \\
240 & 0.40868 & 2.554419733 & 0.521143305 & 0.510508662 & 0.73814088 \\
270 & 0.004088 & 2.297764118 & 0.763330947 & 0.317720089 & 0.845461263 \\
300 & 0.281691 & 1.317672388 & 0.436289003 & 0.177479032 & 0.772942137 \\
330 & 0.333958 & 0.352068281 & 0.236656662 & 0.015310227 & 0.355477005 \\
360 & 0.271974 & 0.127869451 & 0.489291398 & 0.058283223 & 0.192160917 \\
\hline$\%$ & & & & & 0.371668148 \\
Rerata & 0.261051 & 0.852325998 & 0.766384582 & & 0.491680428 \\
\hline
\end{tabular}

Perbandingan nilai secara teoritik dengan GNU Octave dan simulasi solidwork dapat dilihat pada Gambar 8:

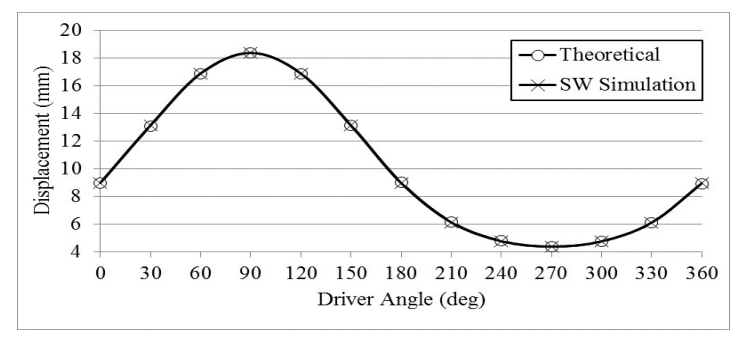

Gambar 8. Perbandingan Displacement Monobike

Berdasarkan gambar 8, linier displacement Monobike secara teoritik dengan GNU Octave maupun dengan Simulasi Solidwork menunjukan nilai yang hampir sama, yaitu rata-rata kesalahan sebesar $0.261 \%$.

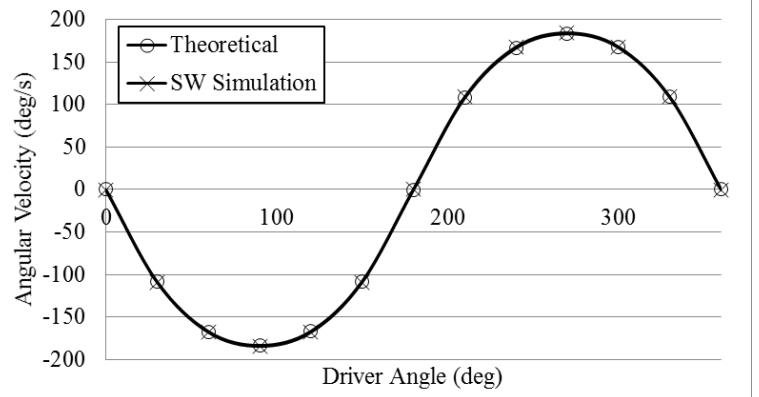

Gambar 9. Perbandingan Kecepatan Angular Monobike

Berdasarkan gambar 9, Kecepatan Angular Monobike secara teoritik dengan GNU Octave maupun dengan Simulasi Solidwork menunjukan nilai yang hampir sama, yaitu rata-rata kesalahan sebesar $0.372 \%$.

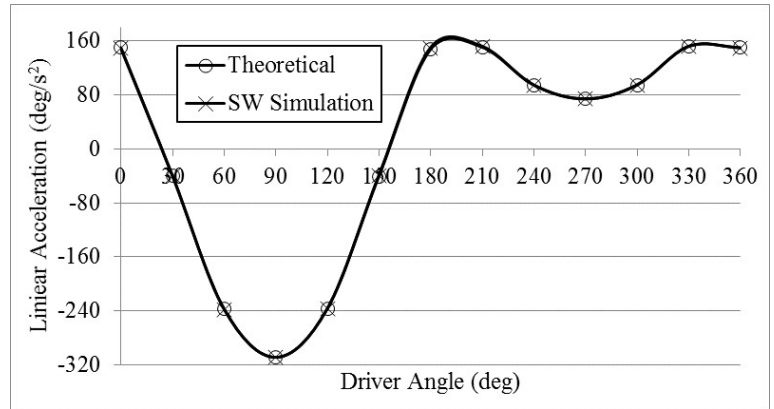

Gambar 10. Perbandingan Percepatan Linier Monobike 
Berdasarkan gambar 10, Percepatan Linier Monobike secara teoritik dengan GNU Octave maupun dengan Simulasi Solidwork menunjukan nilai yang hampir sama, yaitu rata-rata kesalahan sebesar $0.7664 \%$.

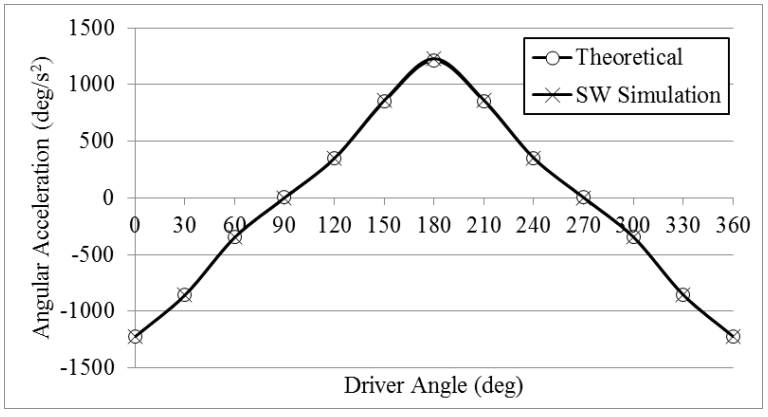

Gambar 11. Perbandingan Percepatan Angular Monobike

Berdasarkan gambar 11, Percepatan Angular Monobike secara teoritik dengan GNU Octave maupun dengan Simulasi Solidwork menunjukan nilai yang hampir sama, yaitu rata-rata kesalahan sebesar $0.492 \%$.

\section{Kesimpulan}

Berdasarkan hasil penelitian teoritis dan simulasi Solidworks, nilai perpindahan, kecepatan dan akselerasi sangat dekat. Kesalahan rata-rata untuk perpindahan linier adalah 0,261\%, kecepatan linier $0,852 \%$, percepatan linier $0,7664 \%$, kecepatan sudut $0,372 \%$, dan percepatan sudut $0,492 \%$.

Analisis kinematik pada mainan mekanik monobike secara teoritis dan simulasi Solidworks, hasilnya kurang lebih sama, sehingga dapat dikatakan bahwa penelitian ini akurat. Solidworks direkomendasikan sebagai perangkat lunak yang dapat digunakan untuk mensimulasikan gerakan dalam analisis kinematik.

\section{Ucapan Terimakasih}

Dalam kegiatan penelitian ini penulis ingin mengucapkan terima kasih kepada:

1. DIKTI melalui hibah Penelitian Dosen Pemula sehingga penulis memiliki kesempatan untuk menyumbangkan pemikirannya.

2. Perguruan Tinggi Teknologi Ronggolawe Cepu, Laboratorium Komputer, staf, asisten laboratorium, petugas, yang telah memberikan waktu, sehingga pemrograman dan pengolahan data dapat dilakukan

\section{Daftar Rujukan}

[1]. Arief, S. (2008). Pengenalan GNU Octave. Retrieved from IlmuKomputer.Com website: https://ilmukomputer.org/wpcontent/uploads/2008/04/sarief-octave.pdf

[2]. Gloria, R. (2019). Catat! Tak Sekadar Hiburan , Ini Manfaat Mainan untuk Anak.

[3]. H, Martin, G. (1985). Kinematika dan Dinamika Teknik (Erlangga). Jakarta.

[4]. Juarez, T. (2016). Mono Bike Wooden Toy. Retrieved from https://grabcad.com/library/mono-bike-wooden-toy-1

[5]. Masganti, S. (2015). Psikologi Perkembangan Anak Usia Dini (I). Perdana Publishing.

[6]. Perdana, P. P., \& Assifa, F. (2019). 200 Akademisi dari 7 Negara Bahas Solusi Atasu Anak Kecanduan Gawai. Retrieved from Kompas.com website: https://regional.kompas.com/read/2019/10/17/19334351/200akademisi-dari-7-negara-bahas-solusi-atasi-anak-kecanduangawai

[7]. Wibowo, D. B., Sulardjaka, \& Haryadi, G. D. (2015). Perancangan dan Evaluasi Kinematika Pada Mainan Mekanikal Edukatif. Seminar Nasional Tahunan Teknik Mesin XIV, (Snttm Xiv), 7-8.

[8]. Zamani, L., Hutapea, \& Erwin, M. (2018). Hindari Kecanduan " Gadget ", Anak-anak di Kampung Joho Dikenalkan Permainan Tradisional.

[9]. Zhu, L., Xu, W., Snyder, J., Liu, Y., Wang, G., \& Guo, B. (2012). Motion-guided mechanical toy modeling. $A C M$ Transactions on Graphics, 31(6). https://doi.org/10.1145/2366145.2366146 